\title{
Impact of Consolidated Utilization of Farmyard Manure and Inorganic Fertilizers on Yield and Yield Ingredients of Irrigated Lowland Rice
}

\author{
${ }^{1}$ A. Musa, 'B. B. Shani, ${ }^{2}$ Adamu U. K. \\ ${ }^{1}$ Department of Crop \& Soil science \\ Faculty of Agriculture \\ National Open University of Nigeria \\ ${ }^{2}$ Department of Soil Science \\ Faculty of Agriculture Federal University,
}

Dutse

Email: aliyugusau2020@gmail.com

\begin{abstract}
Consolidated utilization of organic and inorganic fertilizers can improve crop productivity and improve soil condition. Investigation research was carried out with an objective to examine the impact of usage of farmyard manure in combination with three levels of chemical fertilizers [80: 40: 30, 120: 60: 45 and 160: 80: $60 \mathrm{~kg} \mathrm{~N}, \mathrm{P}_{2} \mathrm{O}_{5}$ and $\mathrm{K}_{2} \mathrm{O} \mathrm{ha} \mathrm{h}^{-1}$, respectively] on yield and yield ingredients of irrigated lowland rice. Split-plot design experiment was used during the dry season with and without farmyard manure as main plots and three inorganic fertilizer levels as subplots. Data were collected on grain and straw yield, number of tillers, panicle length, filled grains per panicle, 1000 grain weight and nutrient uptake. The results revealed that application of farmyard manure at $10 \mathrm{tha} \mathrm{a}^{-1}$ increased grain yield of rice by $25 \%$ compared to no farmyard manure control. Close examinations were also obtained on straw yield, tiller number, filled grains per panicle, and 1000 grain weight. There were significant relationships between farmyard manure and inorganic fertilizer treatments. The advantageous impacts of use of farmyard manure were not magnified at growth rates of use of inorganic fertilizers. However, the highest grain yield of rice was gotten with the application of farmyard manure at 10 tha-1 and inorganic fertilizer at 120: $60: 45 \mathrm{~kg} \mathrm{~N}, \mathrm{P}_{2} \mathrm{O}_{5}$ and $\mathrm{K}_{2} \mathrm{O} \mathrm{ha}^{-1}$. The rise in grain yield was due mainly to intense nutrient uptake and number of tillers, filled grains per panicle and 1000-grain weight.
\end{abstract}

Keywords: Farmyard manure; Inorganic fertilizer; yield

\section{INTRODUCTION}

In Nigeria Today, and the world Rice (Oryza sativa L.) has become one of the major food crops produced. Hossain, et al., (2000) reported that it is always produced on lowlands under both fully irrigated or rain-fed conditions. Rice farmers in pre-industrial age utilize Organic materials such as farmyard manure and green manures effectively. But with the improved high yielding cultivars, the utilization of inorganic fertilizers has risen considerably resulting to decrease in the utilization of organic materials. Also, Barker, et al., 
(1985) showed that the impact of risen fertilizer utilization on crop production has been expanded, but rise energy cost is a hindrance to increased utilization of inorganic fertilizer. Utilization of organic matter to meet the nutrient requirement of crops would be an inevitable practice in years to come, particularly for small scale farmers. In Addition, ecological and environment worries over the risen and indiscriminate utilization of inorganic fertilizers have necessitated research on utilization of organic materials as a source of nutrients. (Giller, et al., 1995; Ayoub, 1999). However, Jenssen, (1993) and Palm et al., (1997) suggested that, the utilization of organic manures in isolation is insufficient to meet the large nutritional intakes of recent high yielding breeds. Therefore, a consolidated nutrient management in which both organic manures and inorganic fertilizers are utilized simultaneously has been recommended as the most effective technique to maintain a good conditioned soil system while increasing crop productivity. There is proof from field studies that high and sustainable yields are possible with consolidated utilization of fertilizers and manure (Raman, et al., 1996; Singh et al., 1999). However, it is important to identify the optimum dose of chemical fertilizer required for maintaining adequate supply of nutrients for increased yield, and reduced environmental pollution.

Andriamananjara et al. (2016) reported no effect of FYM on grain yield and plant P uptake in a P-deficit soil in the central highlands of Madagascar. These studies demonstrated the contrasting results. Moreover, their findings have been limited to a specific location with limited environmental variation. Thus, there is a lot of potential for utilization of farmyard manure in the fertilizer schedule of rice and to reduce total dependence on inorganic fertilizers. This study was therefore carried out to examine the effect of a combination of the application of farmyard manure and different levels of inorganic fertilizer on growth, yield and yield ingredients of irrigated lowland rice.

\section{MATERIALS AND METHODS}

\section{Study Area}

An experimental field research was conducted at the Federal College of Education (Technical), Gusau Teaching \& Research Farm at Gusau, Zamfara State, Nigeria $\left(1216^{\circ} \mathrm{N}\right.$ lat., $667 \mathrm{E}^{\mathrm{E}}$ long. and $450 \mathrm{~m}$ above mean sea level). The soil at the experimental site was sandy loam with $\mathrm{pH} 7.8,0.4 \%$ organic carbon, $220 \mathrm{~kg}$ available $\mathrm{N} \mathrm{ha}^{-1}, 17.3 \mathrm{~kg}$ available $\mathrm{P}$ ha-1, and $152 \mathrm{~kg} \mathrm{~K} \mathrm{ha-1.}$

\section{Experimental Details}

\section{Field preparation, Experimental design, Pest control}

A split-plot design experiment with three replicates was conducted during the dry season (February-May) of 2018. The main plots (6m wide and $20 \mathrm{~m}$ long) were treated with and without farmyard manure. Three fertilizer doses [80: 40: 30, 120: 60: 45, and 160: 80: $40 \mathrm{~kg} \mathrm{~N}$ : $\mathrm{P}_{2} \mathrm{O}_{5}: \mathrm{K}_{2} \mathrm{O}$ ha-1] were assigned to the subplots $(6 \mathrm{~m}$ wide and $7 \mathrm{~m}$ long). The crop management practices were the same for all treatments except for the organic manure and fertilizer treatments. Farmyard manure $(18.5 \% \mathrm{C}, 1.46 \% \mathrm{~N}, 0.56 \% \mathrm{P}, 0.5 \% \mathrm{~K}, 0.9 \% \mathrm{Ca}$, and C: N ratio of 12.7) collected from a different source was brought into rice field a day before transplanting at 10 tha $^{-1}$. Application of all available inorganic phosphorus and potassium and one-third of the inorganic $\mathrm{N}$ at initial dose was done during transplanting while the application of the remaining two-thirds of inorganic $\mathrm{N}$ was done in two equal splits at active tillering and at panicle initiation stages. Irrigation application was carried out as recommended for rice farming. 
Ploughing operation was carried out once on the Field, then puddling and flooding with water, three to four times. Thereafter, individual plots of equal size were prepared by bunds. The application of Organic manure and inorganic fertilizers was done uniformly at $15 \mathrm{~cm}$ depth to each plot as per treatment. Wood plank was used to level to the plots, followed by, a day after, application of organic manure and transplanting of rice seedlings of cultivar FARO44 at a spacing of $15615 \mathrm{~cm}$. The plots were saturated with water and the water level in the field was always maintained at 15 to $20 \mathrm{~cm}$ until 30 days after transplanting. All water for $2 \mathrm{~d}$ (mid-season drainage) were drained from the field, subsequently 10 to $15 \mathrm{~cm}$ water level was maintained until a week before final harvest, when the field was allowed to dry for easy harvesting.

The entire experiment recorded zero incidence of deficiency in nutrient or pests and diseases attack. Prophylactic sprays of recommended insecticides and fungicides as necessary were used on the crops to put them in a stable condition. Thereafter the Fields were ensured to be weed free by hand weeding at $20-25 \mathrm{~d}$ intervals.

\section{Data Collection and Analysis}

Data were collected and measured after harvest on grain and straw yield at maturity of all the plants from net plot area $\left(22.5 \mathrm{~m}^{2}\right)$. In order to determine the number of tillers per hill, number of filled grains per panicle, and 1000-grain weight, Subsamples of plants were selected randomly and harvested.

Nitrogen $(\mathrm{N})$, phosphorus $(\mathrm{P})$, and potassium $(\mathrm{K})$ contents were analyzed from subsamples of grain and straw collected at harvest after being oven dried and finely grounded, using micro-Kjeldahl method, vanadomolybo phosphoric yellow color method using spectrophotometer, and by digestion followed by flame photometry (Jackson, 1973) respectively. The uptake of various nutrients was calculated by multiplying concentration of each nutrient and dry weights and expressed in $\mathrm{kg} \mathrm{ha}^{-1}$.

All the data were statistically analyzed suggested by Gomez and Gomez (Gomez, et al., 1984) and where treatment differences were found significant based on results of F-test, critical differences were calculated at $5 \%$ level of probability.

\section{RESULTS AND DISCUSSION}

Table 1, revealed significant effects of different fertilizer treatments on yield and yield attributes of rice. (Table 1). There is significant improvement in number of tillers, number of filled grains, 1000-grain weight, grain yield and straw yield of rice with the application of farmyard manure (Table 1). When treated over no farmyard manure control, grain and straw yields of rice significantly increased by $25 \%$ and $12 \%$, respectively. In the same vein, there were increased by $12 \%, 6 \%$, and $9 \%$, in the number of tillers, number of filled grains, and 1000 grain weights respectively due to application of farmyard manure. This results showed the importance of Organic manure in the improvement soil permeability to air and water and water stable aggregates. The findings here collaborates (Singh, et al., (1994); Pandey,et al., (1999); Mondal, et al., (1998)) which revealed, that soil physical properties and nutrient uptake are greatly improved when organic materials such as farmyard manure were applied. Sharma (1995) further emphasized that when farmyard manure were at $10 \mathrm{t}$ ha-1 contributes $30-70 \mathrm{~kg} \mathrm{~N}^{-1} \mathrm{~h}^{-1}$ in rice while allowing a significant leftover effect on come after crops. Never ending researches on rice have showed increased yield and yield ingredients due to application of farmyard manure (Raman, et al., 1996; Singh, et al., 1999; Nambiar, et al., 1989). 
Table 1. Influences of Application of Farmyard Manure on Grain Yield and Yield Ingredients of Rice (Data Were Averaged Across Fertilizer Treatments)

\begin{tabular}{|c|c|c|c|c|}
\hline Trait & & $\begin{array}{l}\text { No Farmyard } \\
\text { Manure }\end{array}$ & $\begin{array}{l}\text { Farmyard } \\
\text { Manure }\end{array}$ & $\mathrm{CD}(0.05)$ \\
\hline 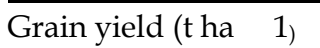 & & 3.07 & 3.84 & 0.35 \\
\hline Straw yield ( $\mathrm{t}$ ha 1 ) & & 4.11 & 4.59 & 0.21 \\
\hline Number of tillers hill & 1 & 12.80 & 14.30 & 1.20 \\
\hline Filled grains panicle & 1 & 68.50 & 72.30 & 2.20 \\
\hline 1000 -grain weight (g) & & 26.83 & 29.31 & 0.62 \\
\hline
\end{tabular}

These relationships established are greatly credited to ameliorated soil organic matter, soil physical, chemical and microbial properties with application of farmyard manure (Gaur, et al., 1984). It further revealed significant relationships between the different inorganic fertilizer levels on grain and straw yield, tiller numbers, filled grains per panicle and 1000grain weight of rice (Table 2). The application of 120: 60: $45 \mathrm{~kg} \mathrm{~N}: \mathrm{P}_{2} \mathrm{O}_{5}: \mathrm{K}_{2} \mathrm{O}$ ha ${ }^{1}$ gave rise to significantly considerable grain yield $\left(3.63 \mathrm{tha}{ }^{1}\right)$ in comparison to that obtained with lower fertilizer levels of $\mathrm{N}: \mathrm{P}_{2} \mathrm{O}_{5}: \mathrm{K}_{2} \mathrm{O}$ ha ${ }^{1}\left(3.17 \mathrm{t}\right.$ ha $\left.{ }^{1}\right)$.

Table 2. Influences of Application of Different Fertilizers Rates on Grain Yield and Yield Ingredients of Rice (Data Were Averaged Across Two Farmyard Manure Treatments)

Fertilizer Treatment $\left(\mathrm{N}: \mathrm{P}_{2} \mathrm{O}_{5}: \mathrm{K}_{2} \mathrm{O}\right.$ kg ha $\left.{ }^{1}\right)$

\begin{tabular}{|c|c|c|c|c|c|}
\hline \multirow{2}{*}{\multicolumn{2}{|c|}{ Trait }} & & \multirow[b]{2}{*}{$\mathrm{CD}(0.05)$} \\
\hline & & $80: 40: 30$ & $120: 60: 45$ & $160: 80: 60$ & \\
\hline Grain yield ( $\mathrm{t}$ ha & 1) & 3.17 & 3.63 & 3.76 & 0.41 \\
\hline Straw yield ( $\mathrm{t}$ ha 1 ) & 1) & 4.05 & 4.43 & 4.53 & 0.29 \\
\hline Number of tillers hill & 11 & 12.5 & 13.4 & 13.8 & 0.90 \\
\hline Filled grains panicle & 1 & 65.0 & 68.0 & 73.0 & 5.80 \\
\hline 1000-grain weight $(\mathrm{g})$ & & 26.86 & 27.58 & 29.80 & 0.75 \\
\hline
\end{tabular}

Nevertheless, application of higher fertilizer level of 160: 80: $60 \mathrm{~N}: \mathrm{P}_{2} \mathrm{O}_{5}: \mathrm{K}_{2} \mathrm{O}$ ha ${ }^{1}$ gave rise to grain yield of $3.76 \mathrm{t}$ ha ${ }^{1}$, which has similarity in statistics to that obtained with application of 120: 60: $45 \mathrm{~kg} \mathrm{~N}: \mathrm{P}_{2} \mathrm{O}_{5}: \mathrm{K}_{2} \mathrm{O}$ ha ${ }^{1}$. Close influences were also observed for straw yield, number of tillers, filled grains per panicle and 1000-grain weight (Table 2). These influences were because of low availability $\mathrm{N}$ and $\mathrm{P}$ in the soil. Results showed significant interaction between application of organic manures and inorganic fertilizer levels for grain yield, straw yield, filled grains and 1000-grain weight. In addition, there was no effect with the increased rate of inorganic fertilizer application on the positive effects of farmyard manure. This is in agreement with Pandey, et al., (1999) and Ghosh, et al., (1999) that showed increased productivity of rice with the combination application of organic and inorganic fertilizer. However, more studies have even showed that organic manures with sufficient quantity of chemical $\mathrm{N}$ fertilizers can give rise to increased dry matter yield and more $\mathrm{N}$ accumulation, then those of traditional inorganic N fertilizers treatments (Singh, et al., 1994; Chung, et al., 2000). An integrated utilization of organic manures and inorganic fertilizers monitors nitrogen losses, preserves soil $\mathrm{N}$ by establishing organic-mineral complexes and thereby make certain uninterrupted $\mathrm{N}$ accessibility to rice plants and higher yields (Sharma, et al., 1988). Additionally, Ghoshal et al., (1995) reported that utilization of different and integrated application of fertilizers and farmyard manure has shown unending yield benefits, and 
these relationships have been credited mostly to the up keep of soil organic matter and microbial activity.

Results on the uptake investigations revealed that use of farmyard manure gave rise to the uptake of $\mathrm{N}, \mathrm{P}$, and $\mathrm{K}$ by 20,12, and $9 \%$, respectively. There were significant interactivities between organic manure and fertilizer treatment. Highest uptake of $\mathrm{N}, \mathrm{P}$, and $\mathrm{K}$ was seen at a fertilizer stage of 120: 60: $45 \mathrm{~kg} \mathrm{~N}: \mathrm{P}_{2} \mathrm{O}_{5}: \mathrm{K}_{2} \mathrm{O}$ ha-1 in conjunction with application of farmyard manure. The rise in $\mathrm{P}$ and $\mathrm{K}$ in farmyard manure application treatment is likely linked to increased availability of these nutrients as a result of improvement in soil structure and increased microbial activity. Singh, et al., (1994) in their studies have revealed that integrated application of farmyard manure and green manure may likely fulfil all the nitrogen requirement ( $150 \mathrm{~kg}$ fertilizer $\mathrm{N} \mathrm{ha}^{-1}$ ) of the improved varieties and yielded better than the application of inorganic fertilizer alone. Continued impacts of amalgamated nutrient management on production of rice-rice cropping system for all seasons revealed that the utilization of inorganic fertilizer $(50 \%)$ and farmyard manure or green manure $(50 \%)$ produced better yields than those gotten by application of $100 \%$ of recommended inorganic N (Katyal, et al., 2000). This agrees with the findings of (Raman, et al., 1996; Singh, et al., 1999; Mondal, et al., 1998; Katyal, et al., 2000) that proper utilization of organic material may bring about rice yield much the same as that gotten with inorganic fertilizers. Consequently, use of organic materials has prospect of in addition enhancing crop yield, as well as lowering reliance on fossil fuel based inorganic fertilizers, thus eliminating hazards brought about by constant and unselective utilization of chemical fertilizers. Researches have also reveal the advantage effects of green manures, and blue green algae on production of rice (Meelu, et al., 1992). Hence, investigations must be carry on with to examine the joined effects of different organic materials such (blue green algae and azolla) and inorganic fertilizer on the production of rice in lowland areas.

\section{CONCLUSION}

This study has revealed that application of farmyard manure at $10 \mathrm{t}$ ha ${ }^{1}$ gave rise to grain yield of rice by $25 \%$. The application of different fertilizer treatments and their relationships with organic manures showed significant effects. Generally, the advantageous effects of farmyard manure on yield, yield attributes, and nutrient uptake were inconspicuous with rising levels of inorganic fertilizer. An excellent yield of rice was gotten by application of 120: 60: $45 \mathrm{~kg} \mathrm{~N}: \mathrm{P}_{2} \mathrm{O}_{5}: \mathrm{K}_{2} \mathrm{O}$ ha ${ }^{1}$ incorporation with farmyard manure. The greater yield obtained with amalgamated utilization of farmyard manure and inorganic fertilizers were credited to risen nutrient accessibility and uptake, arising in higher of number of tillers, filled grains per panicles and 1000-grain weight.

\section{REFERENCES}

Andriamananjara, A., Rakotoson, T., Razanakoto, O.R., Razafimanantsoa, M. P., Rabeharisoa, L., \& Smolders, E. (2016). Farmyard manure application has little effect on yield or phosphorus supply to irrigated rice growing on highly weathered soils. Field Crops Research, 198, 6169. https://doi.org/10.1016/j.fcr.2016.08.029 [Crossref], [Web of Science ${ }^{\circledR}$ ], [Google Scholar]

Ayoub A.T. (1999) Fertilizer and the Environment. Nutr. Cycl. Agroecosys. 55 (2), 117-121.

Barker R., Herdt R.W., Rose, B. (1985) The Rice Economy in Asia: Resources for the Future; Government Printing Office: Washington DC. 
Chung, R.S.; Wang, C.H.; Wang, C.W.; Wang, Y.P. (2000) Influence of Organic Matter and Inorganic Fertilizer on the Growth and Nitrogen Accumulation of Corn Plants. J. Plant Nutr., 23 (3), 297-311.

Gaur, A.C.; Neelakantan, S.; Dargan, K.S. (1984) Organic Manures; Indian Council of Agricultural Research: New Delhi, India.

Ghosh, A.; Sharma, A.R. (1999) Effect of Combined Utilizationd of Organic Manure and Nitrogen Fertilizer on the Performance of Rice Under Flood-Prone Lowland Conditions. J. Agric. Sci. (Cambridge) 132 (4), 461-465.

Giller, K.E.; Cadisch, G. (1995) Future Benefits from Biological Nitrogen Fixation: An Ecological Approach to Agriculture. Plant Soil 174 (1-2), 255-277.

Gomez, K.A.; Gomez, A.A. (1984) Statistical Procedures for Agricultural Research; John Wiley and Sons: New York.

Hossain, M.; Singh, V.P. (2000) Fertilizer Utilization in Asian Agriculture: Implications for Sustaining Food Security and the Environment. Nutr. Cycl. Agroecosys. 57 (2), 155169.

Jackson, M.L. (1973) Soil Chemical Analysis; Prentice Hall of India Ltd: New Delhi, India.

Jenssen, B.H. (1993) Consolidated Nutrient Management: The Utilization of Organic and Mineral Fertilizer. In The Role of Plant Nutrients for Sustainable Food Crop Production in Sub-Saharan Africa; Van Reuler, H., Prins, W.H., Eds.; VKP: Ledschendam, The Netherlands, 89-105.

Katyal, V.; Gangwar, B. (2000) Long-Term Effect of Consolidated Nutrient Manage-ment on Crop Productivity of rice (Oryza sativa)-Rice System. Indian J. Agr. Sci. 70 (2), 110113.

Meelu, O.P.; Jerath, N. (1992) Bio-Fertilizers and Their Potential in Crop Production. In Changing Scenario of Our Environment; Dhaliwal, G.S., Hansra, B.S., Eds.; Punjab Agricultural University: Ludhiana, India, 281-286.

Mondal, S.S.; Chettri, M. (1998) Consolidated Nutrient Management for Sustaining Productivity and Fertility Under Rice (Oryza sativa)-Based Cropping System. Indian J. Agr. Sci. 68 (7), 337-340.

Nambiar, K.K.M.; Abrol, I.P. (1989) Long-Term Fertilizer Experiments in India: An overview. Fert. News 34, 11-20.

Palm, C.A.; Myers, R.J.K.; Nandwa, S.M. (1997) Combined Utilization of Organic and Inorganic Nutrient Sources for Soil Fertility Maintenance and Replenish-ment. In Replenishing Soil Fertility in Africa; Buresh, R.J., Sanchez, P.A., Calhoun, E., Eds.; Soil Science Society of America: Madison, WI, Spec. Publ. No. 51, 193-217.

Pandey, N.; Sarawgi, A.K.; Rastogi, N.K.; Tripathi, R.S. (1999) Effect of Farmyard Manure and Chemical N Fertilizer on Grain Yield and Quality of Scented Rice (Oryza sativa) Varieties. Indian J. Agr. Sci. 69 (9), 621-623.

Raman, K.R.; Singh, M.P.; Singh, R.O.; Singh, U.S.P. (1996) Long-Term Effects of Inorganic and Organo-Inorganic Nutrient Supply System on Yield Trends of Rice-Wheat Cropping System. J. Appl. Biol. 6 (1-2), 56-58.

Singh, N.P.; Sachan, R.S.; Pandey, P.C.; Bisht, R.S. (1999) Effects of Decade Long Fertilizer and Manure Application on Soil Fertility and Productivity of Rice-Wheat System in a Mollisol. J. Indian Soc. Soil Sci. 47 (1), 72-80.

Singh, Y.; Singh, B.; Khera, T.S.; Meelu, O.P. (1994) Consolidated Management of Green Manure, Farmyard Manure, and Nitrogen Fertilizer in a Rice-Wheat Rotation in Northeastern India. Arid Soil Res. Rehab. 8 (2), 199-205.

Sharma, A.R. (1995) Fertilizer Utilization in Rice and Rice Based Cropping System. Fert. News 40 (5), 29-41. 